\title{
KAJIAN DAN PEMODELAN RUMAH SEDERHANA BERDASARKAN PRIVASI DI KOMUNITAS BERPAGAR (GATED COMMUNITY)
}

\author{
Osismat Hia ${ }^{(1)}$, Anna Lucy Rahmawati, ST.,MT ${ }^{(2)}$, Shanty Silitonga, ST., MT. ${ }^{(3)}$ \\ ${ }^{(1)}$ Mahasiswa, Prodi Arsitektur, Fakultas Teknik, Universitas Katolik Santo Thomas Sumatera Utara \\ (2) Staff Pengajar, Prodi Arsitektur, Fakultas Teknik, Universitas Katolik Santo Thomas Sumatera Utara \\ Email: lucyra7011661@gmail.com \\ (3) Staff Pengajar, Prodi Arsitektur, Fakultas Teknik, Universitas Katolik Santo Thomas Sumatera Utara \\ Email: shanty.silitonga@gmail.com
}

\begin{abstract}
Privacy is essential for individual or community because it is aimed at providing a feeling of independence, giving an opportunity to release emotions, help self-evaluate, limit and protect yourself from communication with people. Housing in the gated community is now found to be built solely to be a place to live forgot the privacy. Most of the resident of houses in the gated community are people coming from different regions with different cultures. It is essential to provide the right model for a simple home that can bring about the privacy to residents. This study was categorized into a study using simulation and modeling research strategies. Simulation and modeling research strategy is a form of research using an artificial model of a particular process or system that will be tested through a simulation process, both natural phenomena and man-made phenomena. The phenomenon can be the form, activity, characteristics, changes, relationships, similarities and differences between one phenomenon with other phenomena. The benefit of this research is to find the right home design model based on the privacy of the occupants in a simple house, any elements of the house that can influence it and find a model that can be applied to simple home design in general.
\end{abstract}

Keywords : Privacy, simple house, gated community

\begin{abstract}
Abstrak
Privasi sangatlah penting pada setiap individu ataupun komunitas karena privasi bertujuan untuk memberikan perasaan berdiri sendiri, memberi kesempatan untuk melepaskan emosi, membantu mengevaluasi diri sendiri,membatasi dan melindungi diri sendiri dari komunikasi dengan orang. Perumahanpada komunitas berpagar yang terdapat di perkotaan saat ini banyak ditemukan terbangun hanya semata-matauntuk menjadi tempat tinggal saja dan tidak memikirkan apa dampak yang akan terjadi pada manusia yangtinggal didalamnya, padahal kebanyakan pada rumah yang ada di komunitas berpagar biasanya adalah tempatberkumpulnya beberapa orang yang datang dari beberapa daerah yang tentunya membawa budaya yangberbeda-beda, sehingga sangatlah penting untuk memberikan model yang tepat pada rumah sederhana yangdapat mewujudkan penjagaan privasi pada penghuni di komunitas berpagar. Penelitian ini digolongkan dalampenelitian yang menggunakan strategi penelitian simulasi dan pemodelan. Strategi penelitiansimulasi dan pemodelan adalah suatu bentuk penelitiandengan menggunakan model tiruan dari suatuproses atau sistem tertentu yang akan dikaji/diuji melaluiproses simulasi, baik fenomena alamiah maupun fenomena buatan manusia. Fenomena itu bisa berupabentuk, aktivitas, karakteristik, perubahan, hubungan,kesamaan dan perbedaan antara fenomena yang satudengan fenomena lainnya. Manfaat penelitian ini yaitu menemukan model desain rumah yang tepatberdasarkan privasi penghuni pada rumah atau rumah sederhana, elemen apa saja pada rumah yang dapatmempengaruhinya serta menemukan suatu model yang dapat diterapkan pada desain rumah tinggal sederhanasecara umum.
\end{abstract}

Kata Kunci: Privasi, rumah sederhana, dan komunitas berpagar 


\section{Pendahuluan}

Perumahan pada komunitas berpagar yang terdapat di perkotaan saat ini banyak ditemukan terbangun hanya semata-mata untuk menjadi tempat tinggal saja dan tidak memikirkan apa dampak yang akan terjadi pada manusia yang tinggal didalamnya terlebih dalam melindungi privasi penghuni yang tinggal didalam rumah, padahal kebanyakan pada rumah yang ada di komunitas berpagar adalah tempat berkumpulnya beberapa orang yang datang dari beberapa daerah yang tentunya membawa budaya yang berbeda-beda juga.

Privasi membantu seseorang atau sekelompok orang untuk mengatur jarak personalnya, kapan ingin mendekat dan kapan ingin menjauh.Privasi dibutuhkan oleh siapapun, kapanpun dan dimanapun, agar diperoleh perasaan aman dan nyaman di dalam melakukan aktivitasnya, termasuk juga saat berada di dalam rumahnya (Sativa, 2004). Di dalam kajian tentangarsitektur lingkungan dan perilaku, rumah tidak hanya dianggap sebagai tempat berlindung tetapi juga ditekankan perlunya faktor lain dalam menentukan bentuk dan pola.

Pada saat ini perkembangan komunitas berpagar di Medan terkhusus di Kecamatan Medan Selayang sangatlah pesat, dan banyak diantaranya yaitu rumah dengan tipe yang sederhana.Desain rumah sederhana sebenarnya sudah mengupayakan pengaturan privasi.Namun karena keterbatasan luasan bangunan dan ruang, seringkali pengaturan privasi menjadi tidak efektif.

Berdasarkan uraian pada latar belakang permasalahan di atas,penulis tertarik untuk menelusurinya sebenarnya Bagaimanakah model sebaiknya dalam rumah sederhana berdasarkan privasi? Diwujudkan dalam elemen apa sajakah pengaturan privasi tersebut?.

\section{Landasan Teori}

\subsubsection{Privasi}

Gillmor (dalam Prophesy, 2011) mendefenisikan Privasi sebagai hak dari setiap orang untuk melindungi aspek-aspek pribadi kehidupannya untuk dimasuki dan dipergunakan oleh orang lain.Rapoport (1997) mendefinisikan privasi sebagai suatu kemampuan untuk mengontrol interaksi, kemampuan untuk memperoleh pilihan-pilihan dan kemampuan untuk mencapai interaksi seperti yang diinginkan.Sedangkan Marshall (dalam Wrightman \& Deaux,1981) mendefenisikan bahwa privasi menunjukkan adanya pilihan untuk menghindarkan diri dan keterlibatan dengan orang lain dan lingkungan sosialnya. Holahan (dalam Laurens, 2004) mengatakan ada enam jenis privasi yang terbagi dalam dua golongan.Golongan pertama adalah keinginan untuk tidak diganggu secara fisik.Golongan ini terwujud pada tingkah laku menarik diri.

1. Keinginan menyendiri (solitude). Privasi dapat diperoleh karena dibatasi oleh elemen tertentu sehingga bebas melakukan apa saja dan bebas dari perhatian orang lain.

2. Keinginan menjauh (seclusion) dari pandangan dan gangguan suara tetangga atau kebisingan lalu lintas

3. Keinginan untuk intim dengan orang-orang misalnyadengan keluarga atau orang tertentu saja. Privasi diperoleh tidak pada lingkungannya, tetapi yang terbangun di tengah-tengah kegiatan.

Berbagai tempat dipilih untuk mendapatkan privasi tertentu, misalnya seseorang yang ingin menyendiri, akan lebih memilih teritori publik yaitu tidak ada seorangpun yang mempunyai kontrol terhadap siapa yang bisa masuk ke dalam ruang tersebut. Namun orang yang mencari suatu hubunganyang lebih dekat lebih sering memilih teritori primer,yaitu ia mempunyai kontrol yang cukup terhadap siapa saja yang masuk ke dalam ruang yang bersangkutan.

Golongan kedua adalah keinginan untuk menjaga kerahasiaan diri sendiri yang terwujud dalam tingkah laku hanya memberi informasi yang perlu, yaitu:

1. Keinginan merahasiakan diri sendiri (anonimity). Privasi yang diperoleh ketika berada diantara sesama di daerah orang lain sehingga seseorang bebas berperilaku berbeda dengan yang biasa dilakukannya, tetapi tidak ingin diketahui identitasnya. Keinginan untuk tidak mengungkapkan diri terlalu banyak kepada orang lain (reserve). Privasi ketika seseorang dapat mengontrol sepenuhnya 
kondisi bahwa ia tidak dapat diganggu dan ia yakin merasa aman karena memiliki batasan psikologis terhadap adanya gangguan. Orang yang berada di sekitarnya menghargai dirinya yang ingin membatasi komunikasi tentang dirinya dengan orang lain.

2. Keinginan untuk tidak terlibat dengan para tetangga (non-neighboring). Tidak suka kehidupan bertetangga. walaupun ada kecenderungan pada golongan kedua ini untuk merahasiakan sesuatu tentang diri sendiri, antara privasi dan kerahasiaan terdapat perbedaan yang hakiki. Perbedaan antara kedua konsep itu adalah privasi merupakan konsensus masyarakat dan hak individu yang diakui oleh masyarakat. Sementara itu, kerahasiaan lebih mempunyai konotasi negatif, tidak disukai masyarakat dan tidak ada kaitannya dengan hak individu.

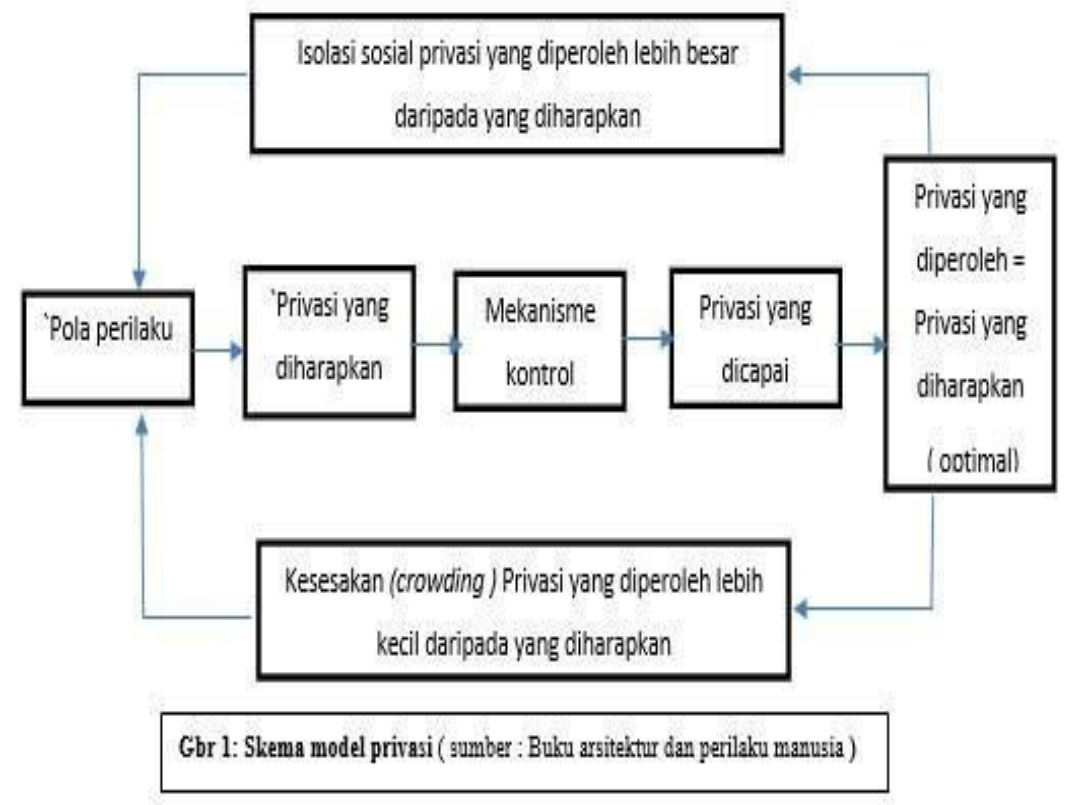

Dapat diartikan inti dari privasi adalah adanya manajemen informasi dan manajemen interaksi sosial sehingga aksespada dirinya tidak terlalu terbuka atau ada hal-hal yang tidak perlu diketahui oleh manusia lainnya.

Privasi merupakan tingkatan interaksi atau keterbukaan yang dikehendaki seseorang pada suatu kondisi atau situasi tertentu.Tingkatan privasi yang diinginkan itu menyangkut keterbukaan atau ketertutupan, yaitu adanya keinginan untuk berinteraksi dengan orang lain, atau justru ingin menghindar atau berusaha supaya sukar dicapai oleh orang lain (Dibyo Hartono, 1986).

\subsubsection{Tujuan Privasi}

Ada empat tujuan privasi (Laurens,2004), yaitu:

1. Memberikan perasaan berdiri sendiri, mengembangkan identitas pribadi. Privasi merupakan bagian penting dari ego seseorang atau identitas diri. Khususnya dapat digunakan seseorang untuk mengevaluasi diri, merenung bagaimana hidupnya telah berjalan, bagaimana hubungan dengan sesamanya dan apa yang harus dilakukannya.

2. Memberi kesempatan untuk melepaskan emosi. Dalam kesendirian seseorang bisa berteriak keraskeras, menangis, memandang wajahnya sendiri di cermin, dan berbicara dengan dirinya sendiri. Masyarakat bisa membuat seseorang mampu menahan emosinya sehingga tidak meledakkannya di depan umum kecuali dalam peristiwa tertentu seperti kematian.

3. Membantu mengevaluasi diri sendiri, menilai diri sendiri. Kurangnya kontrol atas lingkungan fisik ataupun sosial menimbulkan rasa kurangnya otonomi atau independensi seseorang. Lingkungan fisik dapat berperan sebagai mediatorantara privasi dan kontrol. Orang-orang kaya mampu mengontrol 
aksesnya pada orang lain dan akses orang lain terhadapnya hampir di setiap saat karena ia mampu menyediakan ruang-ruang pribadi.

4. Membatasi dan melindungi diri sendiri darikomunikasi dengan orang lain. Salah satu alasan seseorang mencari privasi adalah membatasi dan melindungi percakapan yang dibuatnya. Apabila seseorang ingin berbicara dengan seorang teman mengenai hal yang bersifat pribadi, ia akan mencari tempat yang dianggapnya privat.

\subsubsection{Fungsi Privasi}

Altman (1975) menjabarkan beberapa fungsi privasi. Pertama, privasi adalah pengatur dan pengontrol interaksi interpersonal yang berarti sejauh rnana hubungan dengan orang lain diinginkan, kapan waktunya menyendiri dan kapan waktunya bersama-sama dengan orang lain. Privasi dibagi menjadi dua macam, yaitu privasi rendah yang terjadi bila hubungan dengan orang lain dikehendaki, dan privasi tinggi yang terjadi bila ingin menyendiri dan hubungan dengan orang lain dikurangi. Fungsi privasi kedua adalah merencanakan dan membuat strategi untuk berhubungan dengan orang lain, yang meliputi keintiman atau jarak dalam berhubungan dengan orang lain. Fungsi ketiga privasi adalah memperjelas identitas diri. Dalam hubungannya dengan orang lain, manusia memiliki referensi tingkat privasi yang diinginkannya. Ada saat-saat dimana seseorang inginberinteraksi dengan orang lain (privasi rendah) dan ada saat - saat dimana la ingin rnenyendiri dan terpisah dari orang lain (privasi tinggi). Untuk mencapai hal itu, ia akan mengontrol dan mengatur melalui suatu mekanisme perilaku, yang dijelaskan oleh Altman sebagai berikut:

\section{a). Perilaku verbal}

Perilaku ini dilakukan dengan cara mengatakan kepada orang lain secara verbal, sejauh mana orang lain boleh berhubungan dengannya. Misalnya "Maaf, saya tidak punya waktu".

\section{b). Perilaku non verbal}

Perilaku ini dilakukan dengan menunjukkan ekspresi wajah atau gerakan tubuh tertentu sebagai tanda senang atau tidak senang. Misalnya seseorang akan menjauh dan membentuk jarak dengan orang lain, membuang muka ataupun terus-menerus melihat waktu yang menandakan bahwa dia tidak ingin berinteraksi dengan orang lain. Sebaliknya denganmendekati dan menghadapkan muka, tertawa, menganggukkan kepala memberikan indikasi bahwa dirinya siap untuk berkomunikasi dengan orang lain.

\section{c). Mekanisme kultural}

Budaya mempunyai bermacam-macam adat istiadat, aturan atau norma, yang menggambarkan keterbukaan atau ketertutupan kepada orang lain dan hal ini sudah diketahui oleh banyak orang pada budaya tertentu (Altman, 1975, dalam Dibyo Hartono, 1986).

\section{d). Ruang personal}

Ruang personal adalah salah satu mekanisme perilaku untuk mencapai tingkat privasi tertentu. Ada 4 macam jarak personal space:

1. Jarak intim $(0-0.5 \mathrm{~m})$; Jarak untuk melakukan kontak fisik antara kekasih, sahabat, atau anggota keluarga.

2. Jarak personal $(0.5-1.3 \mathrm{~m})$; Jarak untuk percakapan antar 2 orang yang sudah saling akrab.

3. Jarak sosial $(1.3-4 \mathrm{~m})$; Jarak untuk hubungan yang bersifat formal seperti bisnis, dan sebagainya.

4. Jarak publik $(4-8.3 m)$; Jarak untuk hubungan yang lebih formal lagi seperti penceramah atau aktor dengan hadirinnya.

\section{e). Teritorialitas}

Altman (1975) membagi teritorialitas menjadi 3 macam.Pertama, teritori primer merupakan tempat yang bersifat pribadi yang mencerminkan harga diri dan identitas pemiliknya.M ïsalnya ruang tidur, ruang kerja, pekarangan, dan lain-lain.Kedua, teritori sekunder merupakan tempat yang dimiliki bersama oleh sejumlah orang yang sudah salingmengenal atau orang-orang yang mempunyai kepentingan terhadap 
kelompok itu misalnya tangga bersama, toilet, pintu gerbang, dan lain-lain.Ketiga, teritori umum, yaitu tempat tempat terbuka untuk umum. Misalnya bioskop, taman umum, plaza, dan lain-lain.

\subsubsection{Faktor Privasi}

Gifford (1987) mengatakan ada 3 faktor yang menyebabkan privasi.

\section{Faktor personal}

Faktor Personal (Marshall dalam Gifford, 1987) mengatakanbahwa perbedaan dalam latar belakang pribadi akan berhubungan dengan kebutuhan akan privasi. Dalam penelitiannya,ditemukan bahwa anakanak yang tumbuh dalam suasana rumah yang sesak akan lebih memilih keadaan yang anonim dan reserve saat ia dewasa. Sedangkan orang menghabiskan sebagian besar waktunya di kota akan lebih memilih keadaan anonim dan intimacy.

\section{Faktor situasional}

Kepuasan akan kebutuhan privasi sangat berhubungan dengan seberapa besar lingkungan mengijinkan orang-orang di dalamnya untuk mandiri,sehingga sering sekali beberapa orang menunjukan tingkat privasi yang tinggi pada beberapa situasi. Beberapa hasil penelitian tentang privasi dalam dunia kerja, secara umum menyimpulkan bahwa kepuasan terhadap kebutuhan akan privasi sangat berhubungan dengan seberapa besar lingkungan mengijinkan orang-orang di dalamnya untuk menyendiri (Gifford, 1987).

\section{Faktor budaya}

Pada penelitian tiap -tiap budaya tidak ditemukan perbedaan dalam banyaknya privasi yang diinginkan tetapi berbeda dalam cara bagaimana mereka mendapatkan privasi. Misalnya rumah orang jawa tidak terdapat pagar dan menghadap ke jalan, tinggal dirumah kecil dengan dinding dari bambu terdiri dari keluarga tunggal anak ayah dan ibu.

\subsubsection{Privasi dan Arsitektur}

Tujuan dari perancangan adalah memberikan setiap orang privasi sebesar mungkin sesuai dengan yang diinginkannya meskipun hal ini tidak berarti membangun rumah, kantor,sekolah atau bangunanbangunan umum berupa kompartemen terpisah bagi setiap orang (Laurens,2004).

Di dalam rumah diperlukan adanya berbagai tingkat privasi bagi penghuni rumah.Besarnya rumah tidaklah menjadi penghalang untuk mendapatkan privasi, bahkan seringkali yang terjadi adalah terbatasnya ruang atau penataan ruang yang kurang baik sehingga penghuni rumah tidak mempunyai privasi.Di luar rumah, privasi dapat beragam sebagai suatu fungsi dalam desain di suatu kawasan hunian. Pada hunian bertingkat banyak, seperti apartemen, terdapat berbagai ruang yang memberi privasi sangat rendah dibandingkan dengan ruang di dalam unit apartemen, seperti ruang lobi lift atau ruang publik lain.

Pada umumnya, ruang publik di hunian bertingkat rendah lebih menawarkan privasi daripada di hunian bertingkat banyak.Penghuni mempunyai hubungan sosial dengan tetangganya lebih baik daripada di hunian bertingkat banyak.Sirkulasi pun dapat didesain sedemikian rupa sehingga tidak membiarkan tamu melihat atau melewati ruang tidur untuk menuju toilet umum.Ruang semi publik dalam sebuah kompleks seperti ini dapat dirancang agar penghuni bisa mengamati tamu yang masuk, dapat melihat kegiatan yang terjadi, tetapi sekaligus mengurangi kemungkinan adanya gangguan, memperhatikan privasi visual, audial maupun internasional, khususnya bagi penghuni.

Pada desain perkantoran juga belakangan ini banyak sekali isu yang muncul tentang rendahnya tingkat kepuasan pemakai ruang kerja terhadap privasi ruang mereka.Frank Becker (Becker, 1981 dalam Anisa, 2014) mengatakan, seringkali arsitek merancang ruang kerja dengan berpatokan pada luas meter persegi ruang perorang karena pertimbangan efisiensi padahal, pegawai sangat memerlukan privasi, bahkan lebih penting daripada kenyamanan fisik seperti suhu, ventilasi, perabot, penerangan, view dan estetika secara umum (Farrenkopt,1980 dalam Anisa,2014). Privasi terkait dengan proses psikologis lain seperti mekanisme dan kendali manajemen ruang, komunikasi, identitas dan pertumbuhan. 


\section{Metode Penelitian}

Penelitian ini digolongkan dalam penelitian yang menggunakan strategi penelitian simulasi dan pemodelan lalu dikombinasikan dengan perencanaan dan perancangan. Strategi penelitian simulasi dan pemodelan adalah suatu bentuk penelitian dengan menggunakan model tiruan dari suatu proses atau sistem tertentu yang akan dikaji/diuji melalui proses simulasi, baik fenomena alamiah maupun fenomena buatan manusia. Fenomena itu bisa berupa bentuk, aktivitas, karakteristik, perubahan, hubungan,kesamaan dan perbedaan antara fenomena yang satu dengan fenomena lainnya (Kamus Besar Bahasa Indonesia) setelah itu menggunakan simulasi model yaitu proses pengoperasian (running) suatu model untuk mengkaji karakteristik/perilakuproses atau sistem yang dimodelkan.

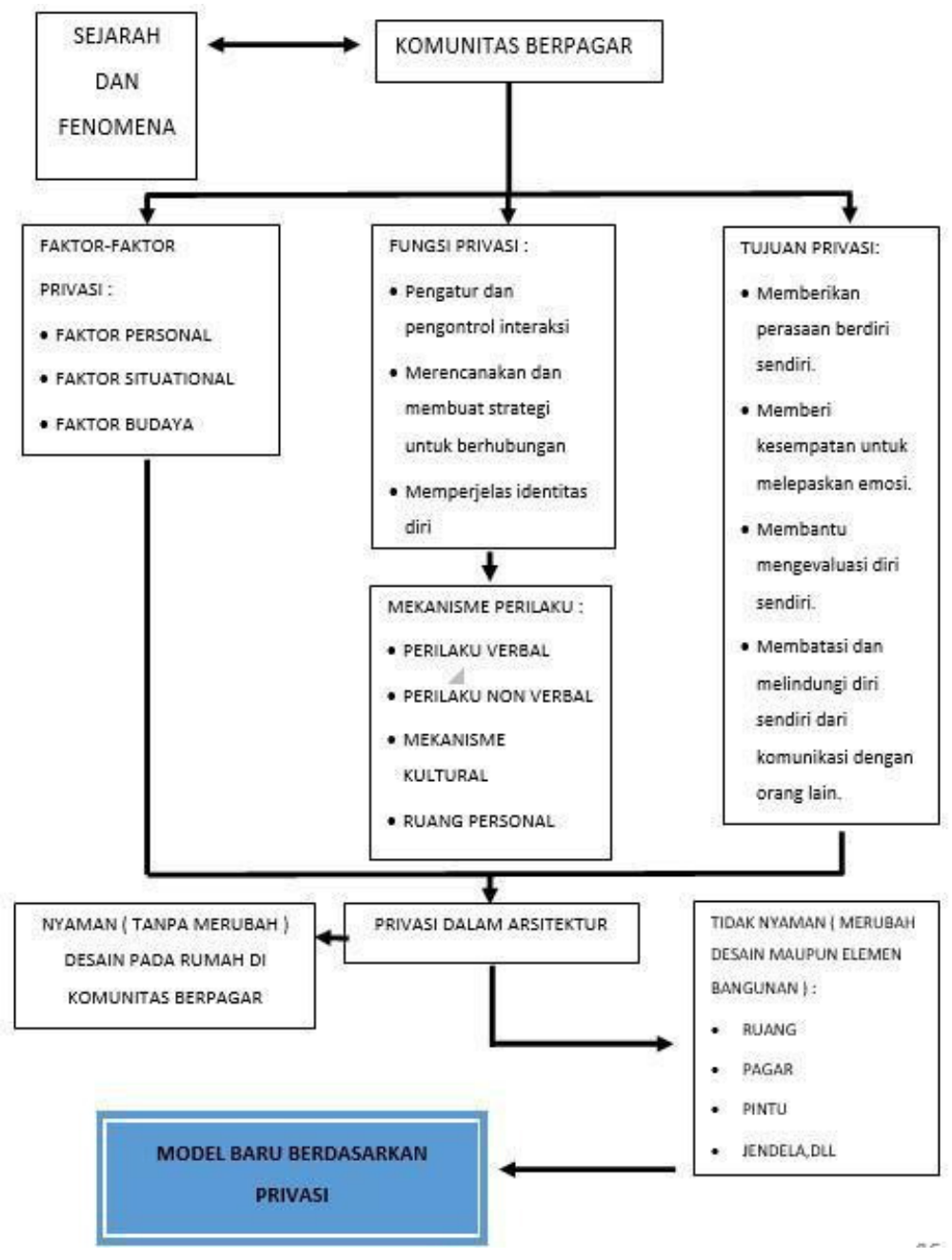

Gambar 1. Skematik Penelitian

\section{Analisa}

Pada Kasus 1, Desain rumah tipe Teratai, mempunyai 6buah ruang yaitu satu ruang tamu, dua kamar tidur, satu ruang keluarga, satu dapur dan satu kamar mandi. 


\subsection{Masalah pada lingkungan}

Pada kasus 1 di rumah tipe Teratai pada komunitas berpagar Debang Taman Sari ditinjau pada lingkungan tidak terdapat masalah pada fungsi ruang, zona ruang dan sirkulasi, namun terdapat masalah pada elemen pembentuk rumah dan lingkungan :

- $\quad$ Elemen pembentuk rumah : Privasi suara kurang terjaga karena rumah tipe teratai disusun berdempetan dengan setengah bata

- $\quad$ Lingkungan :Privasi suara kurang terjaga akibat penyusunan perumahan yang zona privasinya berdempetan

\subsection{Usulan dan model berdasarkan privasi}

\section{Lingkungan :}

- $\quad$ Penyusunan rumah yang bergandengan disusun dengan mendempet ruang yang bersifat privasi dengan ruang yang bersifat privasi.

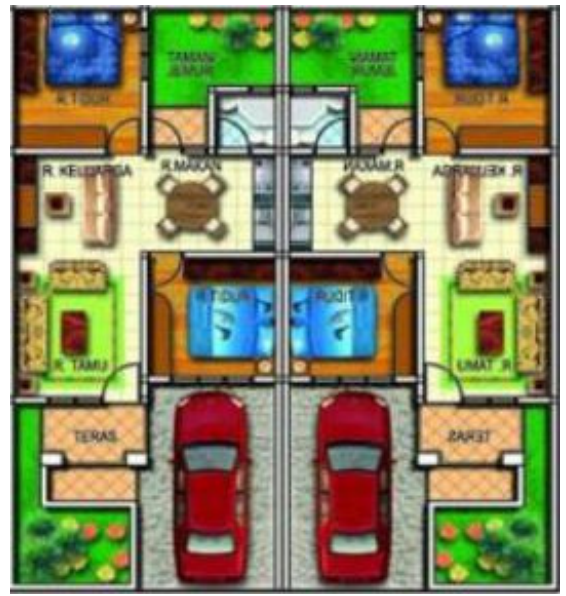

Gambar 2:Ilustrasi PenyusunanRumah

Elemen pembentuk :

( sumber : kesimpulan,2016)

- $\quad$ Dinding pemisah rumah dibuat tidak berdempetan atau dibentuk dengan bahan-bahan kedap suara
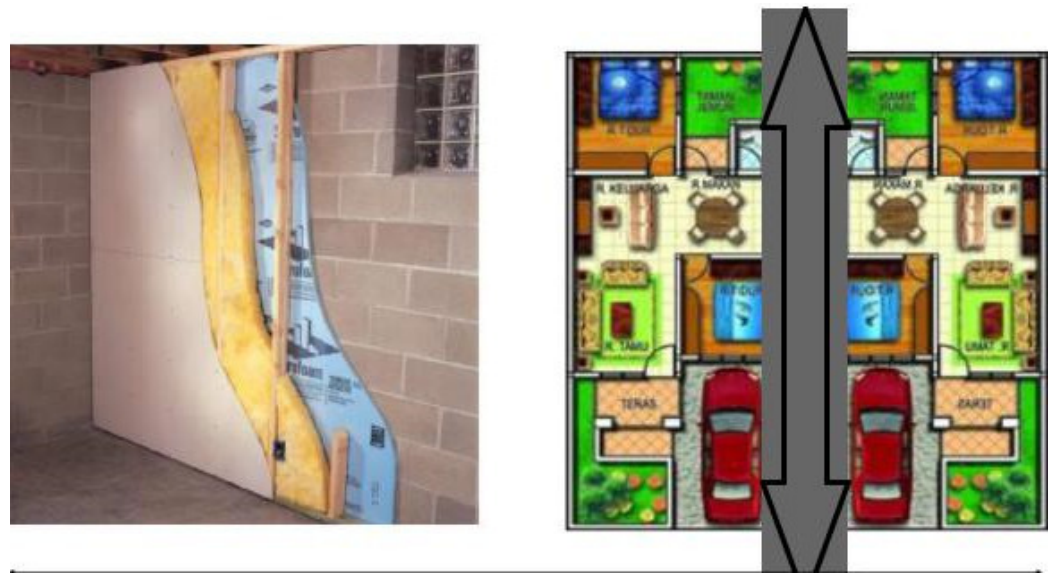

Gambar 3: Ilustrasi dinding kedap suara

( sumber : kesimpulan,2016) 
Sehingga dapat ditarik kesimpulan pemodelan berdasarkan privasi ditinjau dari lingkungan :

- $\quad$ Pada master plan rumah tipe teratai hanya privasi suara yang kurang terjaga

- Cara penyusunan rumah yang berdempetan disusun sesuai zona, yaitu zona privasi bedempetan dengan zona privasi (Gbr 2)

- $\quad$ Elemen pembentuk dinding rumah pada ruang privat diberikan dinding kedap suara (Gbr 3)

\section{Masalah pada desain}

Pada kasus 1 di rumah tipe Teratai pada komunitas berpagar Debang Taman Sari ditinjau pada desain atau denah terdapat masalah pada semua indikator yang mempengaruhi privasi fungsi ruang, zona ruang, sirkulasi, elemen pembentuk rumah, :

- $\quad$ Fungsi ruang : Privasi pandangan terganggu dari ruang tamu, pola ruang tamu yang simetris dengan kamar (Gbr 4)

- $\quad$ Zooning : privasi pandangan dan suara kurang terjaga karena tidak adanya batasan fisik yang jelas dengan zona publik (Gbr 4)

- $\quad$ Sirkulasi : jika ada tamu atau pengunjung, terlihat karena hanya memiliki 1 akses masuk dan keluar (Gbr 4)

- $\quad$ Elemen pembentuk rumah : Privasi pandangan dan suara terganggu karena tidak ada pembatas fisik antara zona publik dan semi publik (Gbr 4)

\section{Usulan dan model berdasarkan privasi}

- $\quad$ Fungsi ruang : Ruang tidur dibuat agar tidak terlihat dari ruang tamu ( tidak berada pada satu garis lurus ).

- Zooning : Zona privat, semipublik, publik, dan servis disatukan, sehingga ruang pembentuk dapat memaksimalkan privasi.

- $\quad$ Elemen pembentuk : Dinding pemisah semi dibuat pada ruang keluarga agar privasi pandangan terjaga,jendela dikurangi pada kamar tidur depan, dan jendela ditambah pada ruang tamu.

- $\quad$ Sirkulasi : adanya pintu alternatif dari samping rumah.

Sehingga dapat ditarik kesimpulan pemodelan berdasarkan privasi ditinjau dari site dan denah:

- $\quad$ dilakukan perubahan pada susunan zona, yaitu ruang tidur ruang dapur dan halaman belakang (Gbr 5)

- $\quad$ adanya sirkulasi masuk alternative (Gbr 5)

- $\quad$ Jendela pada kamar depan dikurangi dan jendela pada ruang tamu di tambah (Gbr 5) 


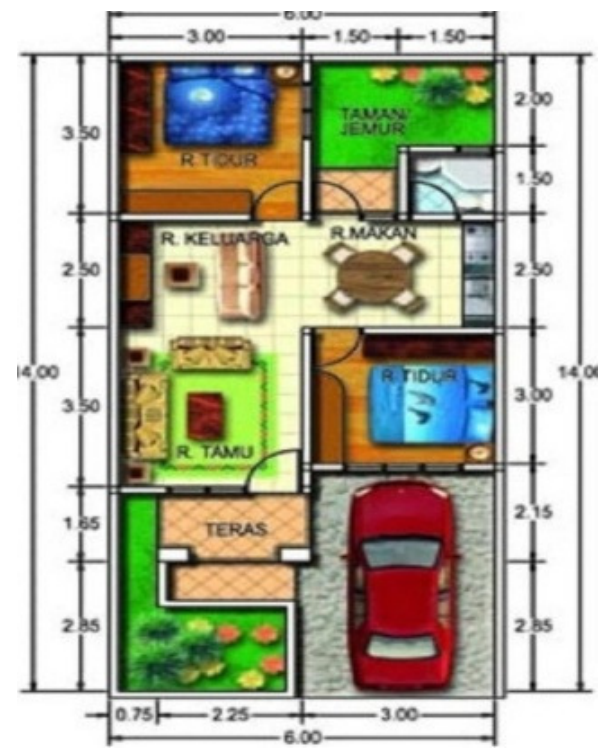

Gambar 4.Denah tipe teratai (DBT) ( sumber : Pribadi )

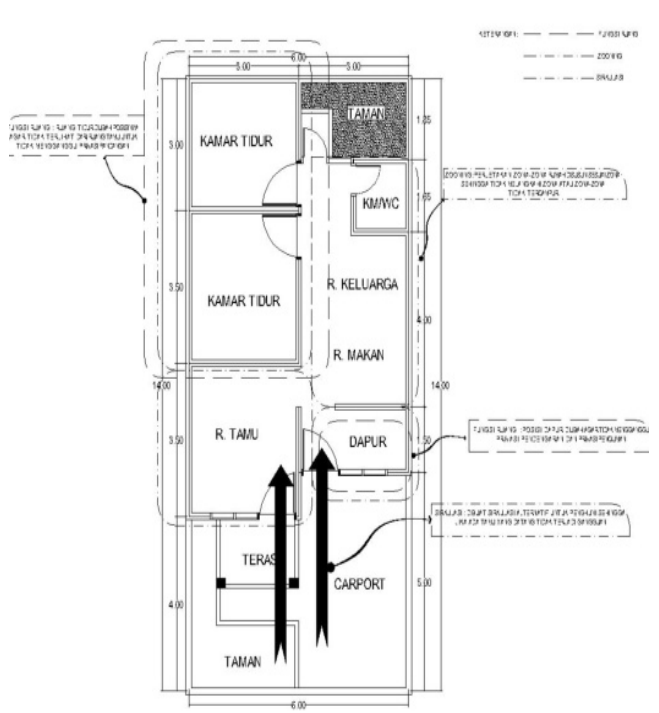

Gambar 5. Model berdasarkan privasi (sumber : Pribadi )

Pada Kasus 2, Desain rumah tipe Akasia, mempunyai 6buah ruang yaitu satu ruang tamu, dua kamar tidur, satu ruang keluarga, satu dapur dan satu kamar mandi. Selain lima ruang tersebut, dilengkapi juga dengan teras dan halaman pada bagian depan dan ruang jemur pada bagian belakang.

\section{Masalah pada lingkungan}

Pada kasus 2, di rumah tipe Akasia pada komunitas berpagar Debang Taman Sari ditinjau pada lingkungan tidak terdapat masalah pada fungsi ruang, zona ruang dan sirkulasi, namun terdapat masalah pada :

- Elemen pembentuk rumah : Privasi suara kurang terjaga karena rumah tipe akasia disusun berdempetan dengan setengah bata

- $\quad$ Lingkungan :Privasi suara kurang terjaga akibat penyusunan perumahan yang zona privasinya berdempetan.

\section{Usulan dan model berdasarkan privasi}

- $\quad$ Lingkungan : Penyusunan rumah yang bergandengan disusun dengan mendempet ruang yang bersifat privasi dengan ruang yang bersifat privasi.

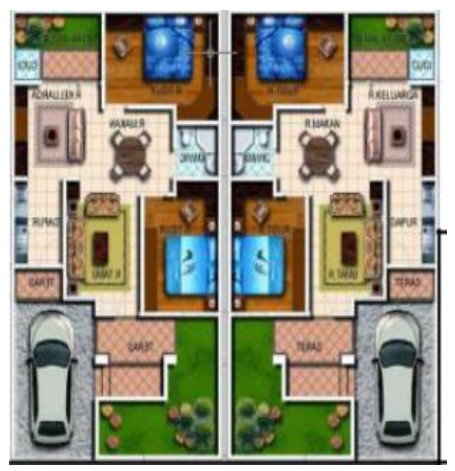

Gambar 6.Ilustrasi Penyusunan rumah ( sumber : kesimpulan,2016 ) 
- $\quad$ Elemen pembentuk : Dinding pemisah rumah dibuat tidak berdempetan atau dibentuk dengan bahan-bahan kedap suara.

Sehingga dapat ditarik kesimpulan pemodelan berdasarkan privasi ditinjau dari lingkungan :

- $\quad$ Pada master plan rumah tipe akasia juga hanya privasi suara yang kurang terjaga (Gbr 6 )

- Cara penyusunan rumah yang berdempetan disusun sesuai zona, yaitu zona privasi berdempetan dengan zona privasi (Gbr 6)

- $\quad$ Elemen pembentuk dinding rumah pada ruang privat diberikan dinding kedap suara (Gbr 6)

\section{Masalah pada desain}

Pada kasus 2, di rumah tipe Akasia pada komunitas berpagar Debang Taman Sari ditinjau pada desain atau denah terdapat masalah pada semua indikator yang mempengaruhi privasi fungsi ruang, zona ruang, elemen pembentuk rumah, :

- $\quad$ Fungsi ruang : privasi penciuman terganggu karena susunan ruang keluarga dan ruang makan.

- $\quad$ Zooning : privasi pandangan dan suara kurang terjaga karena tidak adanya batasan fisik yang jelas dengan zona publik

- $\quad$ Elemen pembentuk rumah : Privasi pandangan terganggu karena pintu masuk kamar belakang yang terekspose dan suara terganggu karena tidak ada pembatas fisik antara zona publik dan semi publik.

\section{Usulan dan model berdasarkan privasi}

- $\quad$ Fungsi ruang : Ruang keluarga dan ruang makan ditukar posisinya.

- Zooning : Zona privat, semipublik, publik, dan servisdisatukan, sehingga ruang pembentuk dapat memaksimalkan privasi.

- $\quad$ Elemen pembentuk : Dinding pemisah semi dibuat pada ruang keluarga agar privasi pandangan terjaga.

Sehingga dapat ditarik kesimpulan pemodelan berdasarkan privasi ditinjau dari lingkungan :

- dilakukan perubahan pada susunan zona, yaitu penukaran posisi ruang keluarga dan ruang makan (Gbr 7)

- $\quad$ adanya batasan fisik pemisah pada ruang yang bersifat publik dan ruang yang bersifat privat. (Gbr 7)

- $\quad$ Pembagian zona yang jelas (Gbr 7)

- $\quad$ Diberi dinding pemisah antara ruang keluarga dan ruang tamu (Gbr 7) 


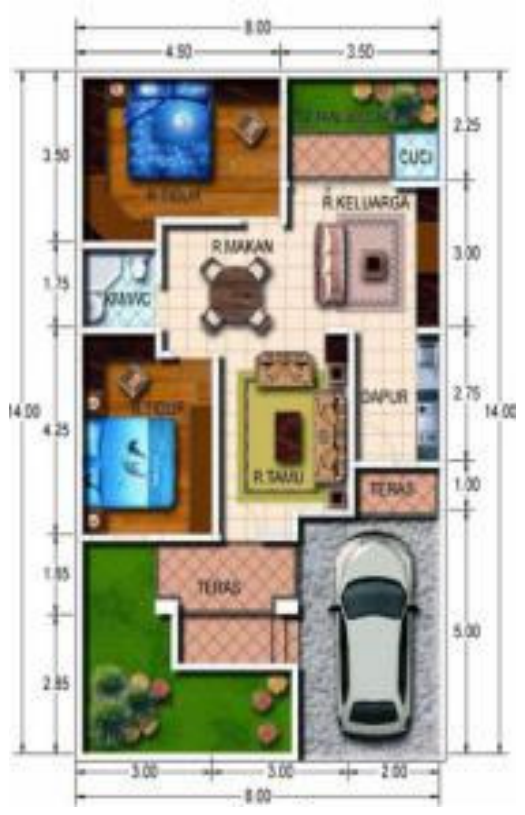

Gambar 8.Denah tipe akasia (DBT) ( sumber : Pribadi )

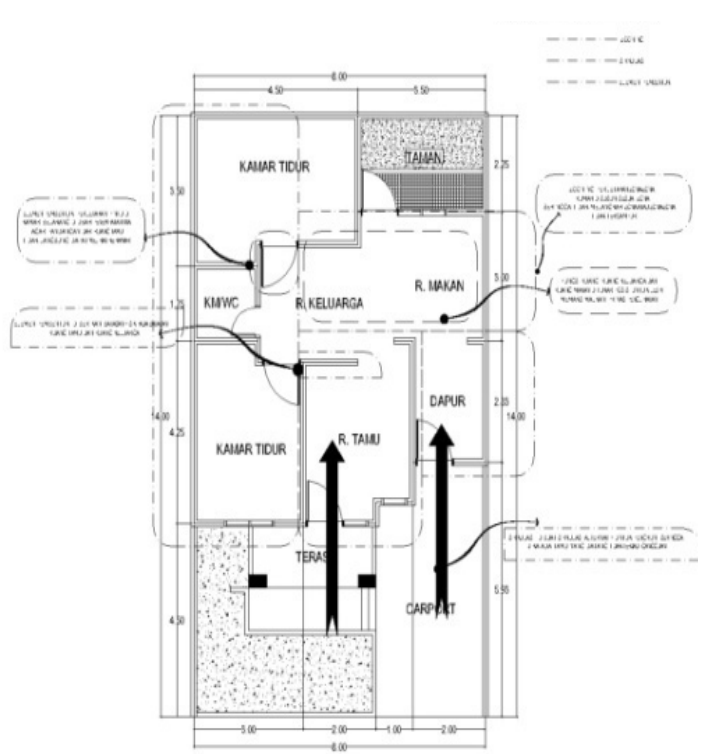

Gambar 9.Model tipe akasia berdasarkan privasi ( sumber: Pribadi)

Pada Kasus 3, Desain rumah tipe Arachis, sebenarnyamempunyai 6 buah ruang yaitu satu ruang tamu, dua kamar tidur, satu ruang keluarga, satu dapur dan satu kamar mandi.

\section{Masalah pada lingkungan}

Pada kasus 3, di rumah tipe Akasia pada komunitas berpagar Debang Taman Sari ditinjau pada lingkungan tidak terdapat masalah pada fungsi ruang, zona ruang dan sirkulasi, namun terdapat masalah pada :

- Elemen pembentuk rumah : Privasi suara kurang terjaga karena rumah tipe akasia disusun berdempetan dengan setengah bata

- Lingkungan :Privasi suara kurang terjaga akibat penyusunan perumahan yang zona privasinya berdempetan

\section{Usulan dan model berdasarkan privasi}

- Elemen pembentuk rumah : Privasi suara kurang terjaga karena rumah tipe akasia disusun berdempetan dengan setengah bata

- Lingkungan :Privasi suara kurang terjaga akibat penyusunan perumahan yang zona privasinya berdempetan

Sehingga dapat ditarik kesimpulan pemodelan berdasarkan privasi ditinjau dari lingkungan :

- Elemen pembentuk : Dinding pemisah rumah dibuat tidak berdempetan atau dibentuk dengan bahan-bahan kedap suara.

- Lingkungan : Penyusunan rumah yang bergandengandisusun dengan mendempet ruang yang bersifat privasi dengan ruang yang bersifat privasi.

\section{Masalah pada desain}

Pada kasus 3, di rumah tipe Arachis pada komunitas berpagar Taman Asoka Asri ditinjau pada desain atau denah terdapat masalah pada semua indikator yang mempengaruhi privasi fungsi ruang, zona ruang, sirkulasi :

- Fungsi ruang : privasi penciuman terganggu karena susunan ruang keluarga dan ruang makan . 
- Zooning : privasi pandangan dan suara kurang terjaga karena tidak adanya batasan fisik yang jelas dengan zona publik

- Sirkulasi : hanya memiliki satu akses sirkulasi utama

\section{Usulan dan model berdasarkan privasi}

- Fungsi ruang : Taman diperkecil sehingga ruang keluarga dan ruang makan serta ruang dapur dapat dipisah ditukar posisinya.

- Zooning : Zona privat, semipublik, publik, dan servisdisatukan, sehingga ruang pembentuk dapat memaksimalkan privasi.

- Elemen pembentuk : Dinding pemisah semi dibuat pada ruang keluarga agar privasi pandangan terjaga.

Sehingga dapat ditarik kesimpulan pemodelan berdasarkan privasi ditinjau dari lingkungan :

- dilakukan perubahan pada susunan zona, yaitu penukaran posisi ruang keluarga dan ruang makan

- adanya batasan fisik pemisah pada ruang yang bersifat publik dan ruang yag bersifat privat.

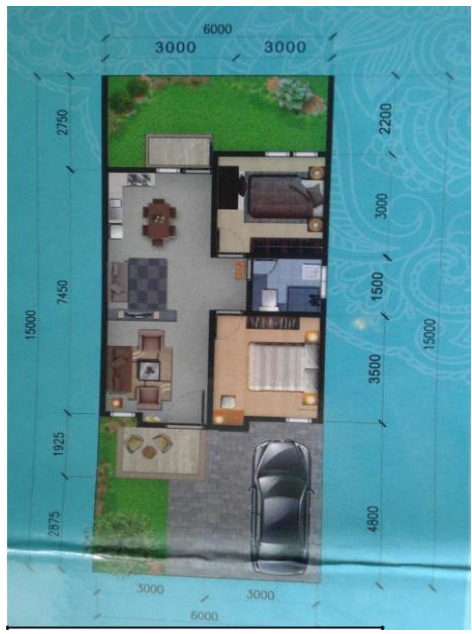

Gambar 10.Denah tipe arachis (TAA)

( sumber : Pribadi )

\section{Kesimpulan}

Penulis menemukan beberapa kesimpulan yang didapatkan dari penelitian mengenai kajian dan pemodelan berdasarkan privasi di komunitas berpagar (Gated community).

- Secara umum model desain untuk sebuah rumah sederhana tidak dapat dirancang dan dijadikan mirip seutuhnya untuk setiap wilayah,karena prinsip dari perancangan yang selalu melihat potensi dan masalah yang ada pada lahan,dan permintaan dari penghuni.

- Namun dalam prinsipnya perancangan yang dapat menjadi model rumah sederhana berdasarkan privasi dapat diwujudkan dalam beberapa aspek yaitu pertama aspek lingkungan; Penyusunan rumah yang bergandengan disusun dengan mendempet ruang yang bersifat privasi dengan ruang yang bersifat privasi dan menggunakan dua dinding pada batasan rumah serta rumah yang berhadap hadapan sebaiknya dibuat berselang-seling.Untuk saluran drainase ditutup dengan batasan yang dapat dibuka sehingga dalam pemeliharaan dapat mudah.

- Dalam aspek sirkulasi; Pengaturan sirkulasi dibuat dua alternatif yaitu sirkulasi utama dengan sirkulasi alternatif buat penghuni.Sirkulasi tidak digunakan untuk aktivitas lain.Sirkulasi tidak digunakan untuk meletakkan perabot. 
- Dalam aspek elemen pembentuk rumah; Elemen pembentukrumah yang sangat mempengaruhi kebutuhan privasi penghuni berdasarkan kebutuhan yaitu dilihat dari materi pembentuk dari elemen prembentuk rumah, susunan elemen pembentuk rumah, jumlah elemen pembentuk rumah yang diberikan.Pintu : pintu dibuat dua pada depan rumah sebagai elemen pembentuk rumah untuk keluar dan masuk penghuni.Jendela : jendela yang ada pada depan rumah terbuat dari bahan single sidded window sehingga orang dari luar tidak dapat melihat kedalam rumah.Dinding : dinding pemisah antara rumah dibuat dari bahan yang kedap suara, Dinding-dinding pemisah setiap fungsi ruang dibuat dengan fisik yang jelas, Dan pada ruang yang bersifat privasi dan publik dipisahkan secara fisik oleh pemisah yang bersifat semi.Ventilasi : pada ruang yang bersifat servis diberikan ventilasi atau exhaust pan untuk memberikan keterjagaan privasi berdasarkan indra penciuman.

- Dalam aspek fungsi ruang; Menyediakan ruang untuk mewadahi kegiatan sehari-hari: publik-semi publik-privat. Susunan ruang didesain dengan memberikan batasan yang bersifat fisik pada setiap perubahan fungsi ruang untuk penghuni maupun orang yang bertamu.

\section{Daftar Pustaka}

Asiz , Rang Faridha, 2008, Fenomena GatedCommunity di Perkotaan, FT UI Jakarta

Haryadi; Setiawan, B, 1995, Arsitektur Lingkungan dan Perilaku, Proyek Pengembangan Pusat Studi Lingkungan, Dirjen Dikti, Departemen Pendidikan dan Kebudayaan RI

Laurens, 2004, Arsitektur dan perilaku manusia, Grasindo Jakarta

Sativa, 2004, Konsep Privasi rumah tinggal di Kampung Kauman Yogyakarta.Tesis pascasarjana UGM Yogyakarta

Sarwono, Sarlito Wirawan, 1992, Psikologi Lingkungan, Grasindo, Jakarta

Sativa, 2004, Konsep Privasi rumah tinggal di Kampung Kauman Yogyakarta.Tesis pascasarjana UGM Yogyakarta

(https://a62747.wordpress.com/2011/04/22/pengertian-privasi-teritorialitas-dan-ruang-personal-serta-hubungannyadengan-lingkungan-prilaku-dan-kepribadian/) diakses 16 November 2015

Wijaya, Hendra, 2010 (http://info-pemodelan sistem.blogspot.co.id/2010/06/definisi-karakteristik-dan-prinsip .html)

Wagiran, Anggi, 2012, Kewenangan Pemerintahdaerah dalam pengelolaan perizinan pembangunan perumahan yang berdampak pada lingkungan yang berkelanjutan 